\title{
Humor and Initiation in Bread Givers
}

\author{
Zhou Jingqiong \\ Faculty of English Language and Culture, Guangdong University of Foreign Studies, People's Republic of China
}

Received November 10, 2019; Revised December 11, 2019; Accepted December 17, 2019

Copyright $\odot 2020$ by authors, all rights reserved. Authors agree that this article remains permanently open access under the terms of the Creative Commons Attribution License 4.0 International License

\begin{abstract}
This paper explores the relationship between the humorous language style, situational humor, and humorous characterization and the initiation of Sara, the protagonist narrator of Bread Givers. Backed with humor and initiation theories, four events in Sara's life will be discussed in detail so as to establish the argument that wide-ranging humor helps narrate and construct the essential steps of Sara's ultimate maturation. These four events are as follows: (1) Sara's departure from her parents' home; (2) Sara's renting a room of her own in New York; (3) Sara's rejection of a rich young man's proposal; and (4) Sara's integration of reconciliation with her tyrannical father into her acculturation. Sara, rising from the ghetto to become a college-educated schoolteacher in the public school, succeeds in achieving maturation and Americanization through her decision for reconciliation with her father, her Jewish legacy by extension.
\end{abstract}

Keywords Bread Givers, Humorous Style, Initiation, Americanization, Jewish Legacy

\section{Introduction}

Identity formation has been of vital and lasting interest in American literature. Mary Dearborn observes in her Pocahontas's Daughters, "the central feature of American identity is the experience of migration that Americans are in fact all descended from immigrants and that American selfhood is based on a seemingly paradoxical sense of shared difference" (3). By the onset of World War I, the United States had been transformed, in Werner Sollors's words, into a "modern, poly-ethnic, and also increasingly urban nation" (qtd. in Ferraro, 380). Consequently, American ethnic women writers have made unusual contributions in this regard. "The most important of the Jewish American headliners of the 1920s was Anzia Yezierska, a sometime schoolteacher and housewife turned creative writer, who between 1920 and 1932 published two collections of short stories and four novels about the trials of Russian Jewish immigrants fighting the economic and social circumscriptions of the East Side" (Ferraro, 387).

In terms of the academic criticism of the theme of initiation in both English and American literature, Jerome Hamilton Buckley has been highly influential with his Season of Youth: The Bildungsroman from Dickens to Golding (1974). The book, though focusing on Victorian novels of initiation, bears relevance to my study of Bread Givers for including such modernist texts as $A$ Portrait of the Artist as a Young Man (James Joyce, 1916). Here is Buckley's outline of the definition of Victorian initiation:

A child of some sensibility grows up in the country or in a provincial town, where he finds constraints, social and intellectual, placed upon the free creative instincts or flights of fancy.... He therefore, sometimes at a quite early age, leaves the repressive atmosphere of home (and also the relative innocence), to make his way independently in the city... There his real "education" begins, not only his preparation for a career but also-and often more importantly-his direct experience of urban life. The latter involves at least two love affairs or sexual encounters, one debasing, one exalting, and demands that in this respect and others the hero reappraises his values. By the time he has decided...the sort of accommodation to the modern world he can honestly make, he has left his adolescence behind and entered upon his maturity. (17-8).

Buckley's definition is criticized as male-oriented for advocating that, to the middle class, a proper vocation be the path to upward mobility. Yet, Buckley's definition seems to be particularly tailored for Sara, the protagonist narrator of Bread Givers. An immigrant girl entrapped in the city ghetto, she is to rise to become a schoolteacher, a vocation that will raise her to the middle class with both social and intellectual dignity.

Humor theories can be a bit complex. Cicero examines, in On the Orator, the techniques of humor in public speaking and contributes an essential division of humor: "There are two kinds of jokes, one of which is based on things, the other on words" (Morreall 17). Such 
categorization of jokes is also applicable to humor. That is, humor can roughly be divided into two types, one based on the matter, the other on the manner, which is the focus of this paper. In line with Cicero, Henri Bergson draws a distinction between the humor that arises from what it depicts and the humor that is created by language (33). Bergson goes one step further to divide humor roughly into three categories: verbal humor, or humor created by verbal play; situational humor, or humor that arises from an event or situation; and humorous characterization (33-65). This paper concentrates on analyzing how figurative language creates plentiful verbal humor, which can lead to an analysis of situational humor and towards the end of the paper, a brief analysis of humorous characterization is also included.

Now a few remarks about the functions of humor are in place. The list of the functions of humor can be long:

To make people laugh, to learn about the world, to find distraction and diversion, to explore taboo subjects without risk, to see comic "villains" in action, to cope with stress and anxiety, to see an authority figure deflated, to see others make mistakes... (Berger, 95-96)

Generally speaking, humor based on the matter tends to be hysterical while humor based on the manner is more subtle. Naturally, Bread Givers, a treasure of subtle humor, is seldom given to laugh-out-loud, hysterical humor. "Scholars have variously observed that ethnic humor exposes social incongruities, release tension, serves as a mode of 'vicarious superiority' and solidifies and/or challenges social in-groups and out-groups" (Shiffman, 49). All of these characteristics, just like the aforementioned list of humor functions, are applicable to the humor in Bread Givers but none are self-sufficient.

This paper focuses on the events in Book II and Book III of the novel, where signs of initiation are obvious of the protagonist narrator.

\section{Sara's Departure from Her Parents' Home}

Bread Givers is a three-part novel. Book I, entitled "Hester Street," deals with the lives of the first generation Jewish immigrants in Hester Street, situated in Manhattan. Reb Smolinsky, a Jewish preacher with whole-hearted devotion to the study of Torah, interdicts the love affairs of his three elder daughters. He arranges marriages for two of them through traditional matchmaking and brokers the marriage of his third daughter himself.

Book II, entitled "Between Two Worlds" embraces the 17-year-old Sara's struggle for and initial success in obtaining an independent identity. Then Sara, exposed to the epiphany of "Knowledge was what I wanted more than anything else in the world," moves to the Midwest to attend college, where, on Commencement day, she wins the essay contest with the apt topic "What the College Has Done for Me" and the $\$ 1000$ reward. In between, Sara almost falls in love with Max Goldstein, a real-estate millionaire from Los Angeles, and finds herself rejecting his proposal when she decides that he doesn't love her, though exciting her as an eloquent and handsome businessman.

Book III concludes with Sara's return to New York City and her employment as a schoolteacher in the public school, her rise from rags to material and intellectual riches, so to speak. She compromises with her tyrannical father by inviting him to move into her house. Toward the end of the novel, Sara reminds the reader of her appropriation of standard English by disparaging the immigrant English of her elementary-school students. She asserts with triumph: "I, Sara Smolinsky, had done what I had set out to do. I was now a teacher in the public schools" (241). An initiation story comes to full fruition.

It seems to be a successful story of assimilation in the traditional sense.

It is a good idea to cast a brief look at Book I, where the economical and social hardships are introduced of the first generation of Russian Jewish immigrants. Amongst the poverty-stricken circumstances, Sara, the youngest of the four Smolinsky girls, has taken the initiative to rescue her family from immediate starvation when all her sisters fail to find employment. Sara, "thin and small, like a dried-out herring" (Yezierska, 7. Subsequent quotations will be cited with page numbers only), is nicknamed "Blood-and-iron" (23). Her mother explains her premature strength and the significance of this name: "When she begins to want a thing, there is no rest, no let-up till she gets it" (20). With a neighbor's kind offer of 25 pennies' herrings, Sara earns 25 pennies' profit and announces her triumph by "throwing the fifty pennies, like a shower of gold, into my mother's lap" (23). "Through this act the novel also establishes her as a dynamic character; just as she, not her sisters, shows initiative in an emergency situation, only she will break the pattern of poverty and dependence on a man, while her sisters end up in marriages not too unlike that of their parents" (Japtok, 111).

Chapter X is the first chapter of Book II, "Between Two Worlds," where the 17-year-old Sara embarks on her pursuit for independence at economical and intellectual levels. But a brief look is in place at what Sara witnesses when she pays a visit to both Bessie's home and Mashah's home, hoping to stay with either elder sister now that she has left her home after having asserted to her tyrannical father's face: "In America, women don't need men to boss them" (137). Bessie and Zalmon, the fish peddler husband, have eleven mouths to feed. Five of them are boys, who "all rush like wild animals. In our house we also had only one sink, but we didn't kill each other to be first" (143), according to Sara's observation. Zalmon orders Sara go home right after breakfast, there is no food and no room for her. Sara decides to pay Mashah, her second elder sister, a visit. It turns out to be another disaster. In Bessie's home, 
at least the man and wife are harmonious. In Mashah's home, she complains to Sara that her husband Moe Mirsky has work, but he keeps buying himself new suits and overcoats that nothing is left for the family. That is why Mirsky "could shine like a prince of plenty" (145) while calling Mashah "nothing but a worn-out rug" (150). However, "Sunshine flowed out of her eyes" (148) when Mashah is with her three kids because she feels she is "holding the riches of heaven" (148) in her arms. Sara accuses Mirsky:"...you piled your children on her neck, starved her, wore her out" (151), but to no avail. She leaves them in indignation.

\section{Sara's Renting a Room of Her Own in New York}

Aptly, Chapter X has a title, "Shut the Door." This chapter serves as Sara's clear rupture between two sections of her life, the first one entrapped in the ghetto of Hester Street and the other one striving for the outside world of freedom, where she will realize her American dream. And her first step is to rent a room of her own, equivalent to Virginia Woolf's prescription for female independence. In her initial imagination for independence, she dreams of becoming a schoolteacher, with a class of schoolchildren looking up at her: "It was like looking up to the top of the highest skyscraper while down in the gutter" (155). At this point, Sara shows her initial progress in acculturation not only through her precise English but also through her acculturated simile: the turn-of-the-century America is best experiencing modernization with skyscrapers in Chicago and New York City. Sara's determination is also embedded in this humorous exaggeration: it's a long way, but she is prepared.

The spatial component in an individual's pursuit for independence in a capitalist country is first introduced early on in Book I. Under the economical pressure of renting out their front room to boarders, Reb Smolinsky defends himself: "I have to be alone in a room to think with God," but meets Mrs. Smolinsky's retort: "Only millionaires can be alone in America. By Zalmon the fish-peddler, they're squeezed together, twelve people, in one kitchen" (13). The French scholar Henri Lefebvre asserts in his groundbreaking The Production of Space: "Though a product to be used, to be consumed, social space is also a means of production" (85); "space is never empty; it always embodies a meaning" (154). Lefebvre views space as a social product that masks the contradictions of its own production. He also illuminates the process of reciprocal causation in which produced spaces influence subjectivity and social relations (62). In his tripartite framework for understanding social space, Lefebvre draws a distinction between "spaces of representation (which determine how space is "conceived"), "spatial practices" (the way in which space is "perceived"), and "representational spaces" (where space is directly "lived"). It is obvious that Lefebvre's spatial theories underline the Smolinskys' perceptions of space, or rather their spatial practices, that is, social space can act as an indicator of economic status and social exclusivity. This constitutes a convincing example of situational humor, where the scholar/Reb Smolinsky is being positioned as superior to other people, including his wife and daughters, who are bread givers to him. Humor is rooted in the comic incongruity of the situation, where all the female family members are wringing their hands about how to make both ends meet, the scholar father, who is literally a parasite living on his female family members, has the cheek to assert his right over the greatest amount of space in the cramped tenement! Yet, metaphorically and paradoxically, this humorous situation lends support to Sara's American dream to become a schoolteacher. Although this is not stated in the novel, the parallel between the scholar father's superior position and the young Sara's dream occupation is implied between the lines. From the first step of Sara's initiation, therefore, humor has played a significant role.

Humor and initiation always have some common ground. According to the incongruity theory of humor (Morreall, 6), all humor springs from the comic incongruity between reality and ideality. Cleanth Brooks and Robert Penn Warren assert that initiation takes place when the adolescent hero "discovers something about the nature of evil, and tries to find some way of coming to terms with his discovery" (344). Put in other words, to achieve intellectual and emotional maturity, the protagonist of an American literary masterpiece must also come to terms with the discrepancy between ideals and reality.

Now Sara is seen having her first breakfast at a bakery apart from home. She recalls once when she was so tired that she tried to close the bedroom and had a break, all her sisters dragged her back to the noisy kitchen where "all my sisters were talking everything at once" (156). Even after all her sisters are married, "mealtime was when Mother let out her bitter heart of worry and Father hammered out his preaching like a wound-up phonograph. In the shop, the girls were talking all at once...each one trying to out-yell the other" (156). The exaggerated descriptions of the noisy domestic and public space strengthen the fact that it is a luxury for a poor girl to have a room of her own. It is not too much to say that this hunger for a private space is both an integral part of Sara's nature and her internalization of mainstream American values.

Here is a list of exaggerated depictions of Sara's ecstasy and despair on the first morning after her arrival in New York City:

1. I opened my arms, burning to hug the new day. The strength of a million people was surging up in me. I felt I could turn the earth upside down with my little finger. I wanted to dance, to fly in the air and kiss the sun and stars with my singing heart. (157) 
2. All the room-to-let signs that I passed seemed like so many doors opening to a new life.... I flew up the five flights of stairs as on wings.

"You have a room?" I asked, my eyes laughing and my voice singing the joy in me.

A hard, mean look hit me in the face.

"I don't take girls." And the woman slammed the door. (157)

3. My heart sank to my feet...

In the rear basement, a fat yentch, in a loose wrapper, showed me a little coffin of a room, dark as the grave. "I got three girls sleeping here already..."

"I want a room all alone to myself." (158)

4. Like a drowning person clinging to a rope, my tired body edged up to that door and clung to it. My hands clutched at the knob. This door was life. It was air. The bottom starting-point of becoming a person. (159)

Finally, Sara manages to find a dirty and shabby room with a broken bed for a monthly rent of six dollars. The third quotation is always used to prove Sara's determination to rent a room for herself only, that is, to have/rent a room of one's own. She knows very well that, if she had stayed on in her parents' home, she would grow up to be exactly like her three elder sisters.

Sara's style of using figurative language doesn't change, be she happy or sad. The above mentioned room-hunting journey is full of twists and turns. But her habit of employing a vivid and exaggerated figurative language is consistent. When she sets out to hunt for a room, she is so excited, "burning to hug the new day. The strength of a million people was surging up in me. I felt I could turn the earth upside down with my little finger"; she wants "to dance, to fly in the air and kiss the sun and stars". All the room-to-let signs are symbols of a new life that she "flew up the five flights of stairs as on wings". And she makes an enquiry with her eyes laughing and her voice singing.

After Sara has met some downright rejections, a landlady shows her "a little coffin of a room, dark as the grave". We the reader are awestruck: these sensory details have painted vivid pictures for us what Sara has encountered on her house-hunting journey, how her laughing eyes and her singing voice are darkened and silenced by the biased attitudes of the property owners and the room small as a coffin and dark as a grave. The whole journey takes a turn favorable to Sara, however. She has ultimately come across a room affordable to her, though tiny, dirty, and shabby.

To strike a balance between earning a living and realizing her target for college-oriented night school study, Sara organizes her daily schedule around three issues: ten hours working in a sweatshop laundry, two hours in the night school, and two more hours to study her lessons in the shabby room. At one point Sara boosts herself with the encouragement: "Great dreams spurred my feet on my way to night school" (160). The noisy circumstances around her shabby room, however, almost drive Sara crazy when, one evening, Sara begins to "hammer into my thick head" (164) the English lesson after night school where she attends a crowded class of fifty students. There is a terrible racket around: Blaring phonographs and automatic pianos, gossiping and jabbering voices from outside the windows, wailing children, hungry barking dogs, shrieking alley cats. "The jarring clatter tore me by the hair, stretched me out of my skin, and grated me under my teeth. I felt like one crucified in a torture pit of noise (164). But then, with fierce determination, "A quietness within me soothed my tortured nerves" (164), Sara, the protagonist narrator, manages to concentrate on her lessons.

The stories of frustration and misery Sara tells about her sisters and their husbands are part of the process of her own acculturation; they work to establish her distance from their deluded notion of America and Americanization. Although she struggles with her poverty and disillusion, Sara implicitly affirms her right to belong to America through self-differentiating humor-a comic sensibility to contrast her nuanced understanding of the New World with more simplistic attitudes about American success and possibility in her father and sisters.

The road from night school to college education is tough, particularly when a teenage girl has to earn her own living from a sweatshop in the same time. Still, Sara's maturation, though never easy and smooth, is achieved for this stage of her life. When going gets tough, the tough gets going.

\section{Sara's Rejection of a Rich Young Man's Proposal}

This event records and reflects Sara's emotional maturity.

In Chapter XIV, "A Man Wanted Me", the spatial component is brought up again, this time it is privileged through Goldstein's greedy ambition to become a tycoon in the realm of real estate in Los Angeles. The spatial component is also stressed in the fact that, throughout Chapter XIV, very little space is reserved for Sara while Goldstein manages to occupy most of it by dwelling on his successful fortune-hunting stories and his future plans for harvesting greater fortunes from his real-estate investments, always squeezing Sara to the spatial edge of narration. How can Goldstein expect Sara to accommodate his ambition and compromise her plan for her education! No wonder that Sara comes up with a solution that satisfies both her nature and nurture: her self-determination doesn't allow her to become Goldstein's property; all her sisters' tragic dependence on men for economical advancement has taught her good lessons.

More important, Sara's rational rejection of Goldstein's proposal is a decision based on her gradually transformed observations of Goldstein's performance and personality 
during their week-long contact. Initially, Max Goldstein leaves sweet impressions on Sara: "That man could wake the dead from their graves" (188) after he says that he likes her better for not fixing herself up for men and for standing on her own feet. Very soon Goldstein has summed up his success stories in Los Angeles after fate has carried him there from New York City. In a few years, he has made great progress, from owning a little stand of imitation jewelry, to a small general store, and to the biggest department store in the village.

"Every step of his struggle to rise, he painted with such colorful pictures, it was like turning the pages of a wonder book right there with him" (191). Sara is conquered: "I gazed up at him feeling like a tiny ant at the feet of a great lion" (191). Goldstein also brags that, although he never went to a school or a college in America, he can hire American college graduates and fire them as he pleases. Sara, though very much carried away, starts making a mental note that she doesn't like this last boast. But a minute later, Sara cannot help being thrilled again when Goldstein strokes her callous palms: "These hands should be playing the piano, not ironing clothes, "and feels his touch to be "finer than silk and velvet" (191).

Goldstein has paid Sara nightly visits during the whole week, taking her out to the vaudeville show, jazz dance, etc.

Here is Sara's high praise, again using exaggerated language, when Max Goldstein takes her out to a Broadway jazz dance:

He took me into his open arms and off we went. Such a dancer as Max was! He glided over the floor, a thing of wings. Lost and forgotten were all thoughts of lessons.

The joy of the dance burst loose the shut-in prisoner in me. I was a bird that had leaped out of her cage. (193)

The very vivid analogy reveals Sara's longing for a change for her hard life as a night school student that must work for long hours during the daytime in a sweatshop. Yet, Sara's strong will and long-term plan refrain her from being absent from night school. Goldstein comes back the next evening, pouring out all his get-rich-quick schemes that would turn him into a millionaire. After feeling amazed in the first evening about his constant talk about real-estate business, Sara feels that he is getting on her nerves with no interest in her studies. When Goldstein finally agrees to spend the evening listening to Sara's reading a story to him, he jerks about restlessly and ends up, instead, pouring out more of his real-estate achievements.

It is obvious to every eye that Goldstein plunges into instant infatuation with Sara. Here is his declaration of love: "There's a magnet inside of you. It pulls me out of my senses.... And yet you set me on fire" (197). For a whole week, Goldstein comes to see Sara every evening, because she is the reason that keeps him in New York City. One evening, he states his life philosophy with the suggestion that she should stop her pursuit of a college education:
It's money that makes the wheels go round. With my money I can have college graduates working for me, for my agents, my bookkeepers, my lawyers. I can hire them and fire them. And they, with all their education, are under my feet. (199)

Although she admits that Goldstein excites her, Sara ultimately comes to the conclusion that, to him, "a wife would only be another piece of property" (200) and "Even in the ecstasy of our kisses, I knew he was not my kind" (201). Sara is making progress on the way to college education while her emotional maturation is firmly rooted in this highly intellectual analysis of Max Goldstein, the millionaire: She and the young man simply don't belong. Love affairs and sexual encounters in the female Bildungsroman are more often debasing and handicapping than exalting. But Sara refuses to be detracted from her pursuit and misled into the romantic mire associated with the stereotype of rich young men.

In addition to Sara's profuse use of figurative language, Chapter 14, "A Man Wanted Me," contains some sparkling moment of humorous characterization, in this case, of Max Goldstein, a positive rags-to-riches stereotype. Upon his arrival in New York, Goldstein seeks employment desperately, driven by hunger. An old pushcart peddler of clothes gives the penniless immigrant boy the job to drive his pushcart and holler for him, "Pay cash clothes." Sara wonders how hard he had struggled with his English. A humorous twinkle leaps into Goldstein's eyes when he replies that that old peddler's English was no better than his and he could not make a distinction between "pay cash clothes" and "pay cats coals, " Max's broken English. Goldstein chatters on about his past with humor and passion:

I didn't understand the words, but my voice was like dynamite, thundering out into the air...

... At the end of the week he was in business for himself. He cried the streets, "Pay cats coals," without even a pushcart... In a month, he had enough money saved to start a little stand of second-hand clothes in Hester Street. (190)

This is an instance of both verbal humor and situational humor, created to convey how humor has played a role in the initiation of Goldstein. "Pay cats coals" clearly reveals that Goldstein has a sense of disparaging humor: instead of being subdued by the strange new circumstances in the host country, he turns himself into the target of humor, turning the fusion of his passion and the social unpredictability to his advantage. Laughter functions as a social adhesive, bonding Goldstein to fellow Jewish immigrants who feel like outsiders in America. As a substitute for cultural ideals as the glue that holds a community together, laughter opens up a more tangible medium by which Goldstein can feel at home, even if only among a handful of his own people. He is a typical 
example of successful assimilation. As Dan Shiffman has claimed, "It is widely acknowledged that having a comic sensibility is often a key element in successful assimilation" (49). Although he plays a negative part as Sara's potential lover and his road to success is way different from that of Sara's, his optimism and resilience foreshadow Sara's ultimate success in her pursuit of the American dream.

This typical "greenhorn" anecdote, however, reminds us of a radically different pattern of struggle and survival toward the American Dream that Reb Smolinsky has followed. There exists some common ground between the two men of two generations: they both have a sense of disparaging humor. Before immigration to the U.S., Reb Smolinsky had been caught up in simplistic and misguided notions of American prosperity and success. When Mrs. Smolinsky attempted to bring her two feather beds to the U.S., Reb Smolinsky sneered at her: "Don't you now it's always summer in America? And in the new golden country, where milk and honey flows free in the streets, you'll have new golden dishes to cook in, and not weigh yourself down with your old pots and pans. But my books, my holy book always were, and always will be, the light of the world" (9). Later, the idealistic Reb Smolinsky fails in his attempt to become a businessman, wasting most of the 500 U.S. dollars his eldest son-in-law had given him as betrothal money by striking a hasty but fraudulent deal with a crook merchant. The funny thing is that Smolinsky doesn't feel embarrassed or heartbroken. He justifies his failed business transaction by first teaching his wife and Sara a lesson instead: "I trust people. The whole world is built on trust. The bank, the mines, the Government never exist unless people trusted each other'" (124).

This is a very humorous situation. The declaration of trust from a victim of business deception amounts to a severe criticism of American social conditions. Then, as usual, he turns to his religious faith to comfort himself: " 'Maybe instead of losing the money I could yet have broken my leg or got myself killed. Maybe God let me off with the mere loss of money to spare me a worse misfortune...' "(124). And then we see the liminal moment of Sara's caricature of her father when he has to console the despairing Mother with further preaching: "Father's face became alive with light. He towered over Mother like an ancient prophet that had just stepped out of the Bible. '... This man who robbed me only pushed me closer into the arms of God.' "(125). This comes from Chapter 7, "Father Becomes a Business Man. " Smolinsky's victimization in this business fraudulence is meant to offer an opportunity for the young Sara to gain valuable knowledge about the nature of evil, an essential component of initiation in American culture (Sequeira, viii). Despite the slashing caricature of Father's innocence and unworldliness, it will turn out that it is Father's invincible religious faith that will play a part in shaping Sara's maturation and ultimate Americanization so that she will manage to strike an impeccable balance between her Jewish legacy and her American autonomy.

\section{Sara's Integration of Reconciliation with Father into Her Acculturation}

The analysis in this section focuses on some instances of very humorous characterization in the novel, where Sara behaves rationally and independently, a dimension of intellectual maturity. Chapter 17, "My Honeymoon with Myself", though a very brief issue of only 5 pages, is a narrative moment of Bread Givers where the ultimate triumph of Sara's individualism is conveyed. After four years of college study, Sara is back to New York as a college graduate, about to become a teacher in the public school. When it's time to rent a room, she selects from the real-estate agent's list of addresses "a sunny, airy room, the kind of a room I had always wanted. Dealing with an agent was as different from the tyranny of landladies, with their personal questions" (240). The unpleasant memory is replaced with the fresh feeling of dignity.

I furnished my room very simply... But when I thought of the crowded dirt from where I came, this simplicity was rich and fragrant with unutterable beauty.

I sat down in my easy chair and let the quiet and the sunshine flow over me. A Triumphant sense of power filled me....

$\cdots$

I celebrated it alone with myself.... The routine with which I kept clean my precious privacy, my beautiful aloneness, was all sacred to me. (240-241)

Sara's spatial practice, as a symbol of social power, is represented against the memory of the unpleasant house-hunting experience she had had as a night school student and a sweatshop ironer. Spatial practices and representational space are never innocent, according to Henri Lefebvre. They can both create social relationship of power. Here Sara has finally become a master of her space of privacy.

Sara's humor shifts to the caricature of Reb Smolinsky, her tyrannical father, in Chapter 18, "Death in Hester Street," Book III. In "Tricksterism and Humor in Bread Givers (1925) by Anzia Yesierska" (Zhou, 2017), the caricature of Reb Smolinsky, though discussed in great detail, focuses on his funny behavior in Book I, "Hester Street", where he not only marries off his three daughters to wrong men, but also shakes off the responsibilities with the argument that "As you made your bed, so you got to sleep on it" (85). His sexism, a natural element of his religion, becomes further entrenched when he turns down Fania's plea to leave her gambler husband and return to New York. Though respected as a saintly rabbi for his devotion to and scholarship of the Torah in the Jewish 
neighborhood, he betrays comic incongruity in his life philosophy and his criteria for selecting candidates for sons-in-law on the basis of their wealth. Sara, the only rebel of the Smolinsky girls, stomps out of her parent's home, with the judgment that Father "lives on the blood of his wife and children" (130). His behavior in Book III, an essential picture to round off his caricature, however, is not even mentioned in the aforesaid paper. As a matter of fact, the understanding of Reb Smolinsky's thematic significance is not complete if his funny behavior and Sara's reconciliation with him towards the end of the book are not taken into account. The caricature of Reb Smolinsky, pursued in Book III, cannot be ignored, because it is an integral part of Sara's criticism and understanding of America's adverse social conditions, which plays an essential role in her initiation.

In Chapter 18, "Death in Hester Street", with a college education and a teacher's certificate in her pocket, Sara, absent from her parents Hester Street home for 6 years, is ready to pay them a visit. In the following quotation, she justifies her absence:

Till now I had no time to be human or enjoy sociability with people. Now I felt like a prisoner just out from a long confinement in prison. Love ached in me more than if I had been with them all the time. It was like a secret wound that I had kept covered for six years. And now that I bared it, it hurt. (242)

This quote contains two analogies which, exaggerated and humorous as usual, have a sound logic: in order to assure economical and intellectual freedom in the future, Sara must first suffer social confinement as a prisoner in terms of time. One can only concentrate his/her energy on one achievement at one time. The analogies vividly convey the hardship that Sara had endured for her dream and ambition, her longing for returning to her parents, and her anxiety about the consequent hurt that the long absence of each other's company may bring about. When Sara returns home, her glimpse of Mother's "gray, wasted face" (244) is full of sorrow: Mother has changed almost beyond recognition. In the last moment of her life, Mother retains whole-hearted devotion to Father when she entrusts him to Sara.

When Mother is dead, the whole house is full of "Wailing and screaming. Tumult and confusion" (252). Sara, for the first time in her life, discovers Father's fragility as a lost child in his heart-breaking monotonous wailing:

My house is fallen! My burden bearer gone! Who'll take care of me now? Who'll cook me my meals? Who'll wash me my clothes? Who'll light me my Sabbath candles? For forty years I protected you, watched over you, prayed for you. Now you're torn away from me. Be a good messenger to God for me. Beg him not to forsake me. (253)
Father, in this intensive moment of sorrow, behaves exactly as a self-centered man as he has always been. Of course, he remembers what Mother had done for him. But very soon he turns to the benefits he had brought Mother and then he turns to god for help. Immediately follows Mrs. Feinstein's prayer, which is as comic as Sara's father's, begging Mother to "Forgive me if I talked evil of you. I take it all back.... Beg God to be merciful to me and spare me all ills'" (253-254). Mrs. Feinstein is a widow that had been cooking for Father when Mother's health declined, with an eye for marrying Father to enhance her life. The sorrow of losing her Mother doesn't spoil Sara's observation and description. Her narrative remains very vivid with sensory details: "As Father crumpled into a heap, spent with grief, the widow Mrs. Feinstein began to howl at the top of her voice, wringing her hands and rocking herself over the coffin" (253). At another moment, Sara's cold observation of her neighbors' behavior borders on a funny carnival: "Other neighbors came in screaming, tearing their hair, and beating their breasts. Falling on the coffin and begging the dead body to forgive their evil talk during her lifetime" (254).

Instead of begging Mother to forgive them, they are begging "the dead body" and "the corpse". These objective words betray a detached stance on the part of Sara, the protagonist narrator, who stands apart from all the women who are "rocking and swaying in a wailing chorus" (254). This foreshadows Sara's upcoming rational judgment.

Now the undertaker is cutting a piece of each of the grief-stricken family members' clothes, a Jewish funeral custom, as a symbolic gift for the departed member. "The undertaker, with a knife in his hand, cut into Father's coat and he rent his garments according to the Biblical law and the ages of tradition. Then he slit my sisters' waists, and they, too, did as Father had done" (255). But when it's Sara's turn, she says no to the undertaker on the grounds that she needs the suit for work and tearing it doesn't bring Mother back to life. Sara's response can be perceived as a funny moment of anticlimax: amid the solemn situation of her mother's funeral, she refuses to behave accordingly, and the reason she has given for her rejection succeeds in degrading the solemn moment to something very trivial. That is, she is not ready to sacrifice her new suit to follow the pointless Jewish custom, which is equivalent to a gift to her departed Mother in others' eyes. This event seems to be indicative of Sara's Americanization at the expense of her Jewish legacy.

Yet, Sara's ultimate maturation, her relationship with Father, with Jewish culture by extension, takes an unexpected twist. In a month after Mother's death, Father marries Mrs. Feinstein, citing the Torah's doctrine for support that "no man needs to wait more than thirty days after his wife's death to marry again" (259). This has taken all the Smolinsky girls aback, all anxious to shake him out of his foolish blindness of believing in the scheming woman who is after Mother's death money/his lodge 
money. According to the neighbors' gossip, Father is "like a bridegroom on a honeymoon" (262). But all too soon, Father's lodge money is used up, and Mrs. Feinstein forces the old rabbi to earn money as a pushcart peddler! Father's hasty marriage with the widow provides one more opportunity for Sara to complete her caricature of the old tyrant: when he marries someone before "Mother not yet cold in her grave" (259) to carry the burden of his house for him, the widow is not ready to warm up his old age for nothing. What a perfect moment of situational irony! Father had selected a wrong woman as his second wife after he had selected wrong men for Sara's three elder sisters! His behavior is mechanical, always a source of humorous characterization.

The situational humor is partially strengthened by the narrative sarcasm directed at Mrs. Feinstein, the scheming woman. She has "thick lips," "fat cheeks," and "huge ears," "an overdressed, overfed cow" (260-263). When she begins to weep hysterically, accusing Sara and her sisters of abandoning Mr. Smolinsky, Sara carries on relentlessly with her sarcastic caricature: "As she sat down, the buttons burst open from the bulging bosom of her waist. Pink ribbons peeped out from a new corset cover. Silk stockings, new shoes. All Mother's death money on her back. And she demanding more, like a leech" (263).

Still, Sara accepts her Jewish boyfriend, her school principal's advice when he reads her mind and reminds her: "'after all, it's from him that you got the iron for the fight you had to make to be what you are now' "(279). Here comes the climax through which Sara's emotional and spiritual threads of maturation are pulled together:

How could I have hated him and tried to blot him out of my life? Can I hate my arm my hand that is part of me? Can a tree hate the roots from which it sprang? Deeper than love, deeper than pity, is that oneness of the flesh that's in him and in me. Who gave me the fire, the passion, to push myself up from the dirt? If I grow, if I rise, if I ever amount to something, is it not his spirit burning in me? (286)

\section{Conclusions}

Such an ending has won the appreciation of many critics. I have shown mine by shedding light on the novel's unique engagement with humorous narrative strategies and their association with initiation of the girl protagonist. Thomas J. Ferraro and Kevin Piper, in their respective book and paper, have praised novels like Bread Givers for discovering ways to be American without excluding the cultural contributions of American ethnic groups. As Piper has observed in "The Making of an American, Counternarration in Louis Adamic's Laughing in the Jungle and Anzia Yezierska's Bread Givers", through "its reuse of ethnic values as the foundation for a unique discourse of American identity, a resolution of the novel's participation in attitudes of both assimilation and resistance becomes possible: Bread Givers moves toward Americanization on its own terms " (100). American acculturation can be fully accomplished without severing the new immigrant's bond with his ethnic legacy. The central American joke addresses the difference between the ideals of American equality and opportunity and the reality that often falls short (Rubin, 9). But Sara Smolinsky succeeds in addressing this joke with humor and her own resolution.

\section{REFERENCES}

[1] Arthur Asa Berger. Blind Men and Elephants: Perspectives on Humor. New Brunswick: Transactions Publishers, 1995.

[2] Henri Bergson. Laughter, An Essay on the Meaning of the Comic. Trans. Cloudesley Brereton and Fred Rothwell. Mineola, New York: Dover Publications, Inc., 2005.

[3] Cleanth Brooks and Robert Penn Warren. Understanding Fiction. New York: Appleton-Century-Crofts, 1971.

[4] Jerome Hamilton Buckley. Season of Youth: The Bildungsroman from Dickens to Golding. Cambridge: Harvard UP, 1974.

[5] Mary V. Dearborn. Pocahontas's Daughters: Gender and Ethnicity in American Culture. New York: Oxford UP, 1986.

[6] Ralph Ellison. Shadow and Act. New York: Random House, 1964.

[7] Thomas J. Ferraro. "Ethnicity and the Marketplace" in The Columbia History of the American Novel, Emory Elliott (ed.). New York: Columbia University Press, 2005. 380-406.

[8] Martin Japtok. Growing Up Ethnic: Nationalism and the Buldungsroman in African American and Jewish American Fiction. Iowa City: University of Iowa Press, 2005.

[9] Henri Lefebvre. The Production of Space. Cambridge and New York: Blackwell, 1991.

[10] John Morreall (ed.). The Philosophy of Laughter and Humor. New York: SUNY, 1987.

[11] Kevin Piper. "The Making of an American, Counternarration in Louis Adamic's Laughing in the Jungle and Anzia Yezierska's Bread Givers." MELUS, Volume 35, Number 1 (Spring, 2010). 99-118.

[12] Louis D. Rubin, Jr. "Introduction, 'The Great American Joke,' " The Comic Imagination in American Literature, Louis D. Rubin (ed.). Washington, D.C.: U. S. Information Agency, 1977.

[13] Issac J. F. Sequiera. The Theme of Initiation in Modern American Fiction. Ann Arbor, Michigan: University Microfilms International, 1978.

[14] Dan Shiffman. "The Americanizing Humor of Louis Adamic's Laughing in the Jungle." Studies in American Humor, New Series 3, No. 5 (1998). 48-63. 
[15] Anzia Yezierska. Bread Givers. New York: Persea Books, 1975.

[16] Zhou Jingqiong. "Tricksterism and Humor in Bread Givers (1925) by Anzia Yesierska." Linguistics and Literature Studies, 5 (2): 2017. 69-77. 